\title{
Population History and Mitochondrial Genetic Substructure of the Rama Amerindians from Nicaragua
}

\author{
Norberto F. Baldi ${ }^{l *}$ and Michael H. Crawford ${ }^{2}$
}

\begin{abstract}
The Rama are a coastal population from southern Nicaragua who in large part were able to resist, at least for a time, the cultural changes and social reorganization brought on by colonial and modern influences. Historical information leaves the Rama origins and biological relationships with nearby extinct and extant groups ambiguous. The objective of this study was to examine the internal genetic microdifferentiation based on the first hypervariable region of the mitochondrial DNA (mtDNA) from a sample of approximately $20 \%$ of the population, and to expand the few available historical and anthropological data on the Rama by exploring the effects of cultural practices and historical events on genetic structure, providing an integrative perspective on the Rama genetic history. When considering differences in the spatial distribution and genetic diversity of the mtDNA haplotypes together with historical information on the Rama, a noteworthy pattern emerges. (a) Haplotypes are differentially distributed among a central Rama community (Punta Águila) compared with the other five peripheral communities (analysis of molecular variance: $F_{C T}=0.10, p<0.001$ ), and their distribution is consistent with the historical relocation of this population after their split from Punta Gorda in the 18th century. (b) Differential genetic signatures found among central and peripheral Rama communities resemble two population histories: one of stability (haplogroup A2) and other of expansion (haplogroup B2), supporting the possibility that these patterns of genetic microdifferentiation between central and peripheral populations resulted from the 18th-century unification in southern Nicaragua of the Rama and a group of Voto migrants from Costa Rica that later split off and moved to the Bay of Bluefields.
\end{abstract}

$\mathrm{T}$ he scant bioanthropological research on contemporary indigenous groups from the Caribbean region of southern Central America (SCA) has resulted in a limited understanding of intergroup relationships and genetic history. To date, most recent molecular research highlights the effects of migration on vast continental regions rather than assessing population dynamics of individual groups that occupy their own changing niches (Reich et al. 2012; Wang et al. 2007). Few studies on SCA have focused on the microevolutionary consequences of cultural practices or the recent effects of historical events such as migration and the selective forces that operate on the structure of small and isolated groups (Barrantes 1993; Thompson et al. 1992). Therefore, our primary goal in this investigation was to expand this knowledge by studying the population microdifferentiation and history of the Rama Amerindians from Central America (Figure 1) though their maternal genetic

\footnotetext{
'School of Anthropology, University of Costa Rica, San Pedro de Montes de Oca, Costa Rica. ${ }^{2}$ Laboratory of Biological Anthropology, University of Kansas, Lawrence, Kansas.

*Correspondence to: Norberto F. Baldi, University of Costa Rica, Escuela de Antropología, Edificio de Ciencias Sociales, Universidad de Costa Rica, San Pedro de Montes de Oca, Costa Rica. E-mail: peto1968@gmail.com.
}

KEY WORDS: POPULATION STRUCTURE, MITOCHONDRIAL DNA, CENTRAL AMERICA, RAMA AMERINDIANS, VOTO AMERINDIANS. 


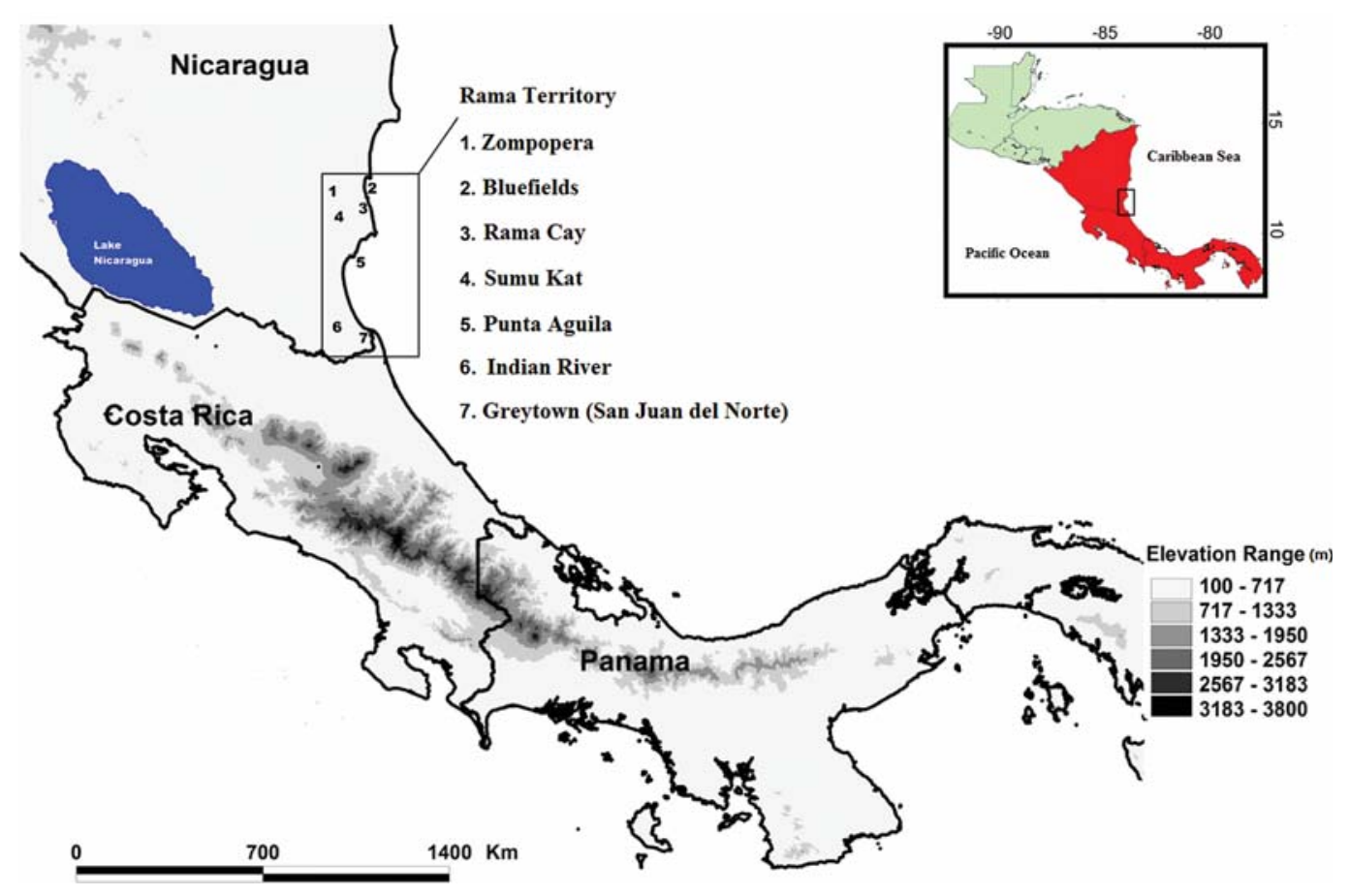

FIGURE 1. Seven Rama localities visited during fieldwork (2007 and 2009) in the southern Mosquitia region of Nicaragua (Baldi 2013). inheritance and exploring the forces of evolution impacting this population due to the influence of recent historical events.

Despite unresolved issues regarding the origins of the Rama, they have been recognized as a culturally (Conzemius 1930; Loveland 1975), linguistically (Constenla 2008; Craig 1990), and biologically unique indigenous population among other Caribbean populations in Nicaragua (D'Aloja 1939; De Stefano 1973; Schultz 1926). Recent studies in anthropological genetics and historical linguistics suggest that the Rama are related to other Chibchan speakers from SCA and northern South America (Constenla 2008; Melton et al.2013) and were significantly impacted by paternal gene flow from Europeans (Melton et al. 2013). These investigations, however, have not integrated historical factors for better understanding the causes of the Rama's internal microdifferentiation that was detected by a previous study based on isonymy and genealogies (Baldi et al. 2014).

The present study examined the level of population microdifferentiation, based on the analysis of the first hypervariable segment (HVSI) of mitochondrial DNA (mtDNA) of six Rama subpopulations in the southern Caribbean region of Nicaragua. Because the Rama maternal genetic inheritance was less impacted by nonindigenous migrants to the region after the 16th century than was the Y-chromosome (Melton et al. 2013), mtDNA was used as an auxiliary method to explore the genetic structure of this population. While the sole use of this marker constrains the analysis of the entire diversity offered by other markers, when combined with ethnohistorical and demographic data mtDNA provides valuable insights into genetic history of a population.

\section{Origin of the Rama}

The pre-Columbian origin of the Rama remains uncertain, and available historical accounts are contradictory (Riverstone 2004; Smutko 1988). Some link the archeological evidence from the Caribbean coast with the Rama (Incer 1975; Riverstone 2004); others, with migrations from Mesoamerica or South America (Clark et al. 1984; Conzemius 1938; Magnus 1974; Stone 1972). Additional hypotheses state that the Rama are an amalgamation of a number of disparate groups from southern Nicaragua and northern Costa Rica or are the direct descendants of extinct Voto, or Boto, who inhabited the northern region of Costa Rica during the colonial period (Riverstone 2004). Contributing to the confusion, the name "Rama" has been used interchangeably with a number of names since at least the 1740s, when Don Diez 


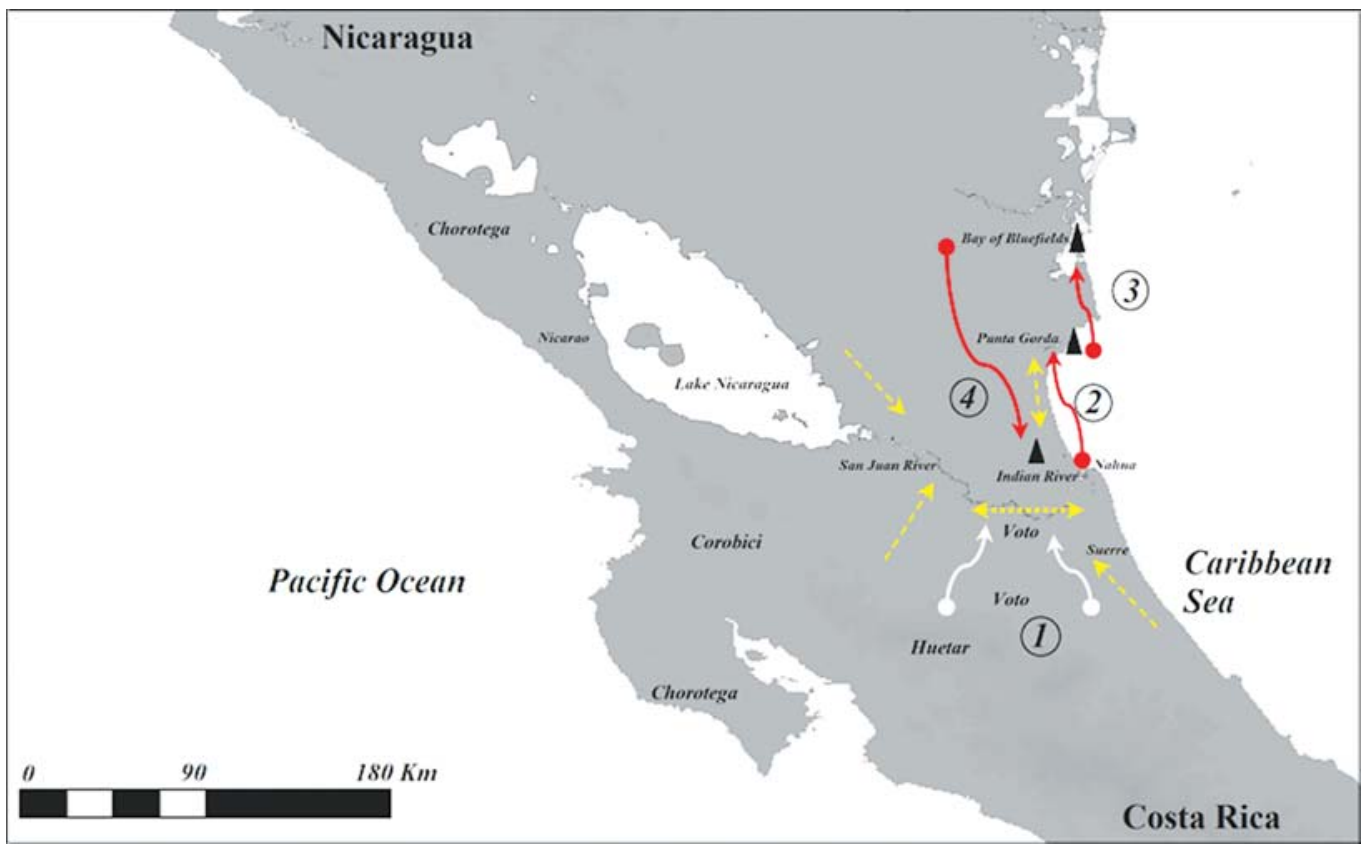

FIGURE 2. Migratory history of the Voto-Rama: (1) In the 16th and 17th century the San Juan River region functioned as a refuge for indigenous populations escaping European colonization in other regions of Costa Rica and likely Nicaragua. Dashed and solid arrows indicate migrations of indigenous populations to the San Juan River region. The San Juan River and its tributaries was also a base for the Voto-Rama and a number of now extinct indigenous groups. (2) In the 18th century the Voto-Rama migrated out from the San Juan River region to Punta Gorda, where another Rama faction, known as "wild Caribs," resided. In the same century, sporadic migrations from Punta Gorda and Indian River protected them against the outbreak of diseases and slave raids. (3) A fraction of the Rama relocated in the Bay of Bluefields and Rama Cay (peripheral group) at the end of the 18th century and early in the 19th century, while another fraction of the Rama remained in Punta Gorda (central group). The isolation of these two groups gives rise to dialectal variants, Rama Cay Creole, and other Creole registers. (4) Overpopulation of Rama Cay and increased conflict and competition for land and marine resources induced migration and recolonization in southern Nicaragua and the Bay of Bluefields region in the late 20th century. Aggregation of the Rama in communities is a recent phenomenon resulting from the pressure for resources by foreign interests and mestizo peasants.

Navarro visited the San Juan River and observed that whether or not some individuals can be distinguished as either "Caribs" (Rama) or "Moscos," they belong to the same nature (Romero 1995). The ambiguity of the chronicles contributes to difficulty faced by historians and anthropologists who wish to identify exact population names and localities.

To avoid confusion due to the interchangeable use of the names "Voto" and "Rama" in historical accounts, we refer here to the post-16th-century population inhabiting the lowlands of northern Costa Rica and the San Juan River surroundings as the "Voto-Rama," to differentiate from the Voto of the foothills of the Cordillera Central, near the Poás and Barva volcanoes, and the lowlands of San Carlos in Costa Rica.

The history of migration of the Voto-Rama from Costa Rica to Nicaragua and its aggregation with the Rama from Punta Gorda is summarized in Figure 2. During the 16th and 17th century, the San Juan River separating Costa Rica and Nicaragua functioned as a refuge for indigenous populations escaping European colonization in other regions of Costa Rica and likely from the Pacific region of Nicaragua. The San Juan River and its tributaries served as a home base for the Voto-Rama and a number of now extinct indigenous groups, such as Tises, Katapas, Abito, Pocosol, and Tori (Ibarra 2011; Solórzano 2000). In the 18th century the VotoRama migrated out from the San Juan River region to Punta Gorda in southern Nicaragua, where a Rama faction also known as the "wild Caribs" resided (Romero 1995). This group is presumably today's Rama.

At the end of the 18th century and early in the 19th century a fraction of the Rama relocated to the Bay of Bluefields and Rama Cay, while another Rama population remained in Punta Gorda. Oral 
traditions compiled by Moravian missionaries (Loveland 1975), as well as ethnographies (Conzemius 1927), indicate that these disparate groups were once a unified population, stating that a group moved to Rama Cay after being compensated by the Miskito kingdom for services rendered in an intertribal war against the Teribe from Costa Rica.

It is not clear if the Voto-Rama were completely assimilated by the Rama of Punta Gorda or if the group that split off Punta Gorda corresponds with either of these two populations. What is assured is that the Rama that inhabit Rama Cay refer to the group at Punta Águila, near Punta Gorda, as the "real Rama" (Jerry Macrea, personal communication, 2009). In consequence, the isolation of these two groups gave rise to two dialectal variants, Rama Cay Creole, spoken mostly at Rama Cay, and a second variant that is spoken to the south, including in Punta Águila (Assandi 1983). In addition, myths of creation gathered from Rama Cay included an account of the migration from Punta Gorda to the Bay of Bluefields in the 18th century (Loveland 1975). These myths pinpointed Corn River, Snook Creek, Cane Creek, Monkey Point, and the Punta Gorda region as localities where Rama emerged before their migration north to the Bay of Bluefields (Loveland 1975; Schnaider 1989).

In the late 20th century overpopulation at the island of Rama Cay increased conflict and competition for land and marine resources with nonindigenous migrants, most of them from the Pacific coast of Nicaragua, which induced the migration and recolonization by the Rama from Rama Cay to southern Nicaraguan locales, such as San Juan del Norte (Greytown), Indian River, and the Bay of Bluefields region. Aggregation of the Rama in communities is a recent phenomenon resulting from the pressure for resources by foreign interests and mestizo peasants (Gobierno Territorial Rama y Kriol 2007).

Based solely on ethnohistorical accounts, the hypotheses of origins of the Rama are difficult to test because of the existing discrepancy of locations, the complexity of population movements, the assimilation process, and the overlapping of cultures and names of the indigenous villages in the 16th century and later. However, the examination of additional mtDNA alongside available historical, archaeological, and linguistic information offers an alternative means of studying the effect of historical events on the genetic structure of the Rama. Future studies using full mitochondrial genomes and additional markers will lead toward a more comprehensive analysis and interpretation of the population dynamics of the Rama.

\section{Materials and Methods}

To investigate the genetic variation among six Rama subpopulations, we collected buccal swabs and mouth rinses for DNA analysis and genealogical information of 190 participants from seven Rama communities along the southern Caribbean coast of Nicaragua during fieldwork in 2009. To these samples, we added 75 additional samples collected by Melton et al. (2013) (total $n=265$ ). Details on geographical locations and general information on each Rama community visited during fieldwork are summarized in Baldi et al. (2014).

During fieldwork each participant signed a consent following the Helsinki protocol for the use of biological samples. The ethical approval of this research was endorsed by the Institutional Review Board (approval no. 16735) at the University of Kansas and accepted by the Rama community and the Gobierno Regional Rama y Kriol in the autonomous region of southern Nicaragua. Cells from swabs and mouth rinses were collected in cryotubes with $750 \mu \mathrm{l}$ of $10 \mathrm{mM}$ Tris, $1 \mathrm{mM}$ EDTA. The samples were then transported to the Laboratory of Biological Anthropology of the University of Kansas for DNA extraction, analysis, and storage.

\section{DNA Extraction}

DNA extractions, restriction-fragment-length polymorphism (RFLP) for haplogroup identification, and polymerase chain reactions for genetic sequencing were performed at the Laboratory of Biological Anthropology. The DNA from mouth rinses obtained during fieldwork was extracted following the Chelex protocol (Walsh et al. 1991), and the DNA from buccal swabs was extracted using the Evogen One method (Evogen Laboratories, Kansas City, KS, USA). Buccal swabs were centrifuged for $4 \mathrm{~min}$ at 10,000 rpm and then $50 \mu \mathrm{l}$ Evogen One product was added to each tube. Tubes were gently vortexed and then heated at $95^{\circ} \mathrm{C}$ for $2 \mathrm{~min}$. The supernatants containing the DNA were transferred into $5.0 \mathrm{ml}$ collection tubes. 
mtDNA HVS-I Sequencing and RFLP Analyses

To characterize haplogroup variation, we first screened samples by RFLP analysis of the coding region. We tested first for haplogroups A2 and B2, which are the most frequent among the Rama (Melton et al. 2013). The remaining samples that did not test positive for these haplogroups were screened for haplogroups Dl and $\mathrm{Cl}$ and examined for African and Eurasian haplogroup variation based on maternal genealogical information and direct sequencing of the HVS-I and HVS-II. RFLP screening for Amerindian haplogroups was performed using the restriction sites +663 HaeIII (haplogroup A2), +8,250 HaeIII, (haplogroup B2), $+13,259$ HincII and +13,262 AluI (haplogroup C1), $+5,176$ AluI (haplogroup D1). Details on the primers, annealing temperatures, reagents, and endonuclease enzymes are given in Baldi (2013). In addition to these analyses, individuals were cross-checked with their respective HVS-I sequence and haplogroup assignation based on PhyloTree.org (build 16) nomenclature (van Oven 2010).

To obtained greater genetic resolution on haplotype variation, we analyzed 174 new mtDNA HVS-I samples from six Rama subpopulations (Sumu Kat, 15; Punta Águila, 21; Indian River, 10; Greytown, 41; Zompopera, 37; and Rama Cay, $80)$. These were added to 30 samples previously reported by Melton et al. (2013). Samples were characterized by the mtDNA HVS-I between the nucleotide position (np) 16,000 and np 16,400 using the Big Dye Terminator version 3.1 Cycle Sequencing Kit on an ABI 3130 Sequencer (Applied Biosystems, Foster City, CA, USA) at the University of Kansas Natural History Sequencing Laboratory. Forward and reverse strands were sequenced for each sample to avoid phantom mutations, errors, and other artifacts. mtDNA chromatograms resulting from the previous analysis were edited using BioEdit (Hall 1999) and compared with the revised Cambridge Reference Sequence (Andrews et al. 1999). Variations in nucleotides deviating from the revised Cambridge Reference Sequence were recorded as DNA sequence variants.

\section{Analytic Procedures}

\section{Genetic Structure and Diversity Measurement}

Genetic structure was approximated using the analysis of molecular variance (AMOVA) (Excoffier et al.
1992) and the $R$-matrix, a statistical technique that permits visualization of the relationships of populations by averaging genetic distances into a variancecovariance matrix (Harpending and Jenkins 1973). AMOVA was calculated based on geographical and kin affiliation criteria (Baldi et al. 2014) using pairwise genetic differences. The $R$-matrix analysis was performed in ANTANA (Harpending and Rogers 1984) and displayed as a principal component analysis (PCA) plot using HVS-I mtDNA sequence data. Tamura and Nei (1993) genetic distances were calculated on the mtDNA sequences and corrected for mutation rate heterogeneity using the $\gamma$-value of 0.26 (Meyer et al. 1999)

For detecting patterns of genetic discontinuity among the Rama subpopulations, Monmonier's algorithm (Monmonier 1973) and the interpolated genetic landscape (Miller et al. 2006) were applied. Monmonier's algorithm is a phylogeographic procedure that detects barriers of gene flow by identifying distances along a network of interconnected points (Dupanloup et al. 2002; Manni et al. 2004). We used Barrier, version 2.2 (Manni and Guerard 2004), to detect such genetic discontinuities. Results were plotted in a three-dimensional geographical grid with $x$-, $y$-, and $z$-axes using the software Alleles in Space (Miller 2005). In this representation, the $z$-axis in the three-dimensional grid represents the genetic differences between populations, and $x / y$-axes represent geographic coordinates. Valleys below the $x / y$-plane represent genetic similarities, and peaks above the $x / y$-plane indicate genetic differences.

\section{Phylogenetic and Chronometric Analyses}

Median joining networks (MJ) of reduced reticulations (threshold $=1, \varepsilon=0$ ) were constructed to determine genetic relationships among haplotypes within the studied subpopulations using mtDNA HVS-I genetic sequences and for two Native American haplogroups (A2 and B2). Networks were generated in Network, version 4.6.1.0 (Bandelt et al. 1999).

We approximated the time of the most recent common ancestor for haplogroups A2 and B2 using the mtDNA HVS-I (np 16,050-16,383) from the constructed MJ networks (Bandelt et al. 1999) with a rate of one mutation every 16,667 years (Soares et al. 2009). Mutational changes were counted from the network by means of the rho statistic $(p)$, 
which represents the average number of mutations between the root haplotype and individuals in the sample.

\section{Results}

\section{RFLP and Haplogroup Characterization}

The RFLP analysis of the Rama sample revealed the presence of haplogroups A2 and B2, which are representative of two of the four major clades present in America: A, B, C, and D (Schurr et al. 1990; Wallace and Torroni 1992). Haplogroup B2, which accounted for $71 \%$ of the sample, was assigned by the presence of the $+8,250$ HaeIII marker identifying the 9-base-pair (bp) deletion (-CCCCCTCTA-) at COII/tRNA ${ }^{\text {lys }}$, and cross-checked with genealogical information. Haplogroup A2, which accounted for $28 \%$ of the total sample, was assigned by the presence of the +663 HaeIII marker and cross-checked with genealogical information. The remaining $1 \%$ of samples belong to haplogroups $\mathrm{H} 2$ and L3. A previous study found the same pattern of Amerindian haplogroup variation among the Rama but in different proportions: A2, 8\%; and B2, 92\% (Melton et al. 2013).

An examination of additional mutational motifs in HVS-I and HVS-II of an individual mtDNA, which was previously incorrectly identified as Cl solely by HVS-I (Baldi 2013), confirmed the presence of the European haplogroup H2 (H2a2ald) through the transitions at np 16172C and np 16263G. An additional sample corresponded to the African lineage L3 (L3hlb2). Both of these haplogroups are signatures of recent genetic admixture among the Rama's gene pool and were assigned through mutation assignments and cross-checked at phylotree.org (van Oven 2010; van Oven and Kayser 2009) and with Mitotool, version 1.1.2 (http://www. mitotool.org/).

Within the Rama population haplogroup B2 is most frequent, particularly among the communities of Sumu Kat, Rama Cay, Bluefields, Greytown, Indian River, and the city of Bluefields. Haplogroup A2 is more frequent in Punta Águila and haplogroups A2 and B2 are equally represented in Zompopera. H2 and L3 lineages appear in Greytown close to the San Juan River between Costa Rica and Nicaragua (Table 1). From the 174 new sequences, nine new haplotypes $(3,4,8,9$,
Table 1. Haplogroup Classification Based on RFLP and HVS-I Sequencing among Seven Rama Subpopulations of Amerindians from Nicaragua

\begin{tabular}{|c|c|c|c|c|c|}
\hline \multirow[t]{2}{*}{ Subpopulation } & \multicolumn{4}{|c|}{ Haplogroup } & \multirow[t]{2}{*}{ Total No. Individuals } \\
\hline & A2 & B2 & $\mathrm{H} 2$ & L3 & \\
\hline Sumu Kat & 3 & 28 & & & 31 \\
\hline Rama Cay & 23 & 88 & & & 111 \\
\hline Bluefields & 0 & 7 & & & 7 \\
\hline Punta Águila & 13 & 9 & & & 22 \\
\hline Greytown & 12 & 32 & $1^{a}$ & $1^{a}$ & 46 \\
\hline Indian River & 4 & 6 & & & 10 \\
\hline Zompopera & 19 & 19 & & & 38 \\
\hline Total & 74 & 189 & 1 & 1 & 265 \\
\hline Percent & 28 & 71 & 0.5 & 0.5 & 100 \\
\hline
\end{tabular}

${ }^{\mathrm{a}}$ HVS-II was additionally sequenced for this sample.

13-17) are added to the seven previously reported by Melton et al. (2013) among the Rama. Haplotypes 3 and 4 correspond to haplogroup A2, and haplotypes 8 and 9 and 13-15 to haplogroup B2. Haplotypes 13 and 14 correspond to haplogroups H2 and L3, respectively (Table 2).

\section{Genetic Diversity and Neutrality Tests}

Haplotype diversity values $(h)$, the number of variant sites $\left(\Theta_{s}\right)$, and the nucleotide diversity $\left(\Theta_{\pi}\right)$ were calculated only for Native American sequences in order to approximate the forces of evolution acting on each Rama locality (Table 3). Based on the magnitude of $h$, Punta Águila and Rama Cay are the most diverse communities among these localities. The diversity estimator $\Theta_{s}$ shows a similar picture of diversity compared with the nearly uniform nucleotide diversity values across localities, except for Sumu Kat, that which shows lower nucleotide diversity values $\left(\Theta_{\pi}=2.74\right)$. In addition, the numbers of polymorphic sites and haplotypes, as well as selective neutrality tests, were calculated for the Rama as a whole. The Rama have 15 Amerindian haplotypes, low nucleotide diversity values $(\pi=$ 0.012 ), and a moderate haplotype diversity value of 0.637 , suggesting a relatively low genetic diversity shared among individuals.

\section{Haplotype Networks and Chronometry}

To compare the sequence haplotype variation among Punta Águila, Zompopera, Rama Cay, Greytown, Indian River, and Sumu Kat, an MJ network was constructed from mtDNA HVS-I sequences from np 16,050 to np 16,383. Two separate networks 

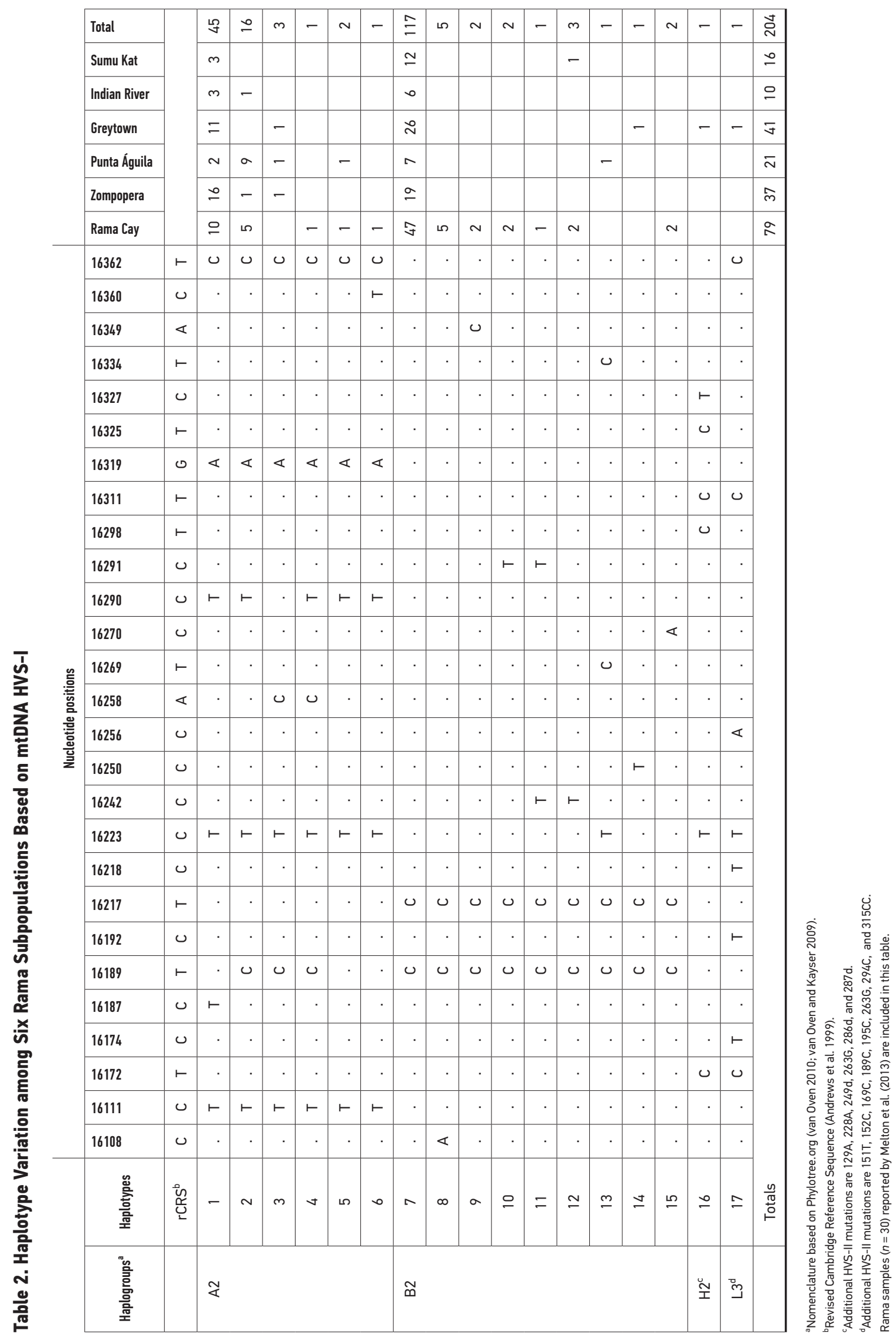

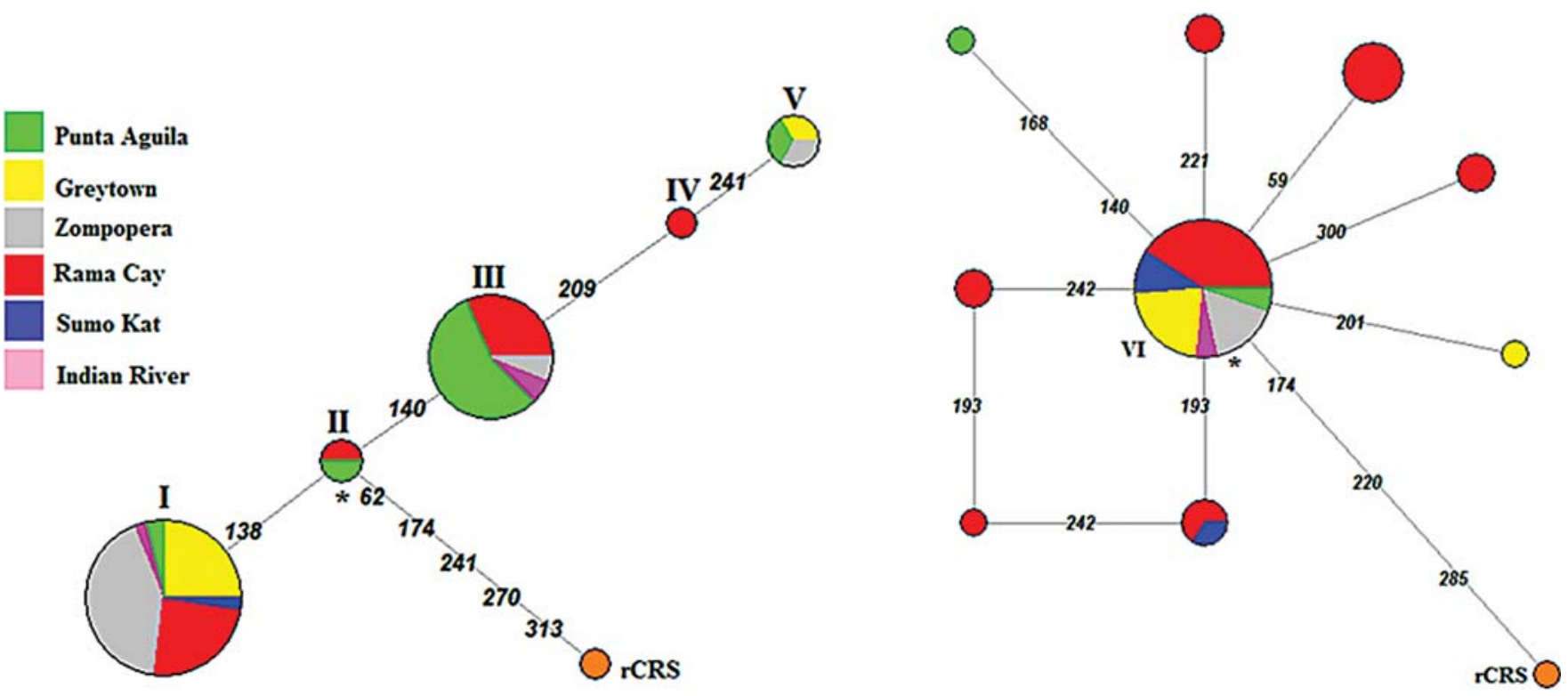

FIGURE 3. Network of haplotypes defined by sequence variants from HVS-I (np 16,050-16,383) from six Rama subpopulations. Left, haplogroup A2 (node I, haplotype 1; node II, haplotype 5; node III, haplotype 2; node IV, haplotype 6; node V, haplotype 3). Right, haplogroup B2 (node VI, haplotype 7). Circles representing haplotypes are proportional to their total frequency, with the frequency of individuals within a subpopulations in different colors. Mutations are shown on the linking branches of nodes, and ancestral haplotypes are marked with an asterisk.

for haplogroups A2 and B2 were generated, showing large and small satellite nodes that represent cluster of haplotypes (I-VI, Figure 3).

The general topology of the haplogroup A2 (Figure 3, left) shows a stable population where genealogies are structured by nodes or groups of haplotypes of related lineages that coalesced to an ancestral node. Haplogroup A2 has five nodes that correspond with haplotypes 1-3, 5, and 6 from Table 2. Only haplotype 5 (basal node II) is shared between Rama Cay and Punta Águila. This node shares branches with two other major nodes: I (haplotype 1) and III (haplotype 2). Haplotype 1 is more frequent in Zompopera, Rama Cay, and Greytown, whereas haplotype 2 is more frequent in Punta Águila. Two other low-frequency haplotypes, haplotype 6 (node IV) and haplotype 4 (node V), diverged from node III.

In contrast, the topology of the B2 network (Figure 3, right) shows a starlike phylogeny typical of an expanding population, where a central node shares most of the haplotypes across subpopulations and low-frequency haplotypes radiate from it. The most frequent haplotype of haplogroup B2 occurs in the ancestral node VI (haplotype 7). This haplotype is shared among other Central American populations (Kuna, Emberá, Zapatón-Huetar,
Table 3. Molecular Diversity Indexes and Neutrality Tests among Rama Subpopulations

\begin{tabular}{lcccc} 
Population & \multicolumn{5}{c}{ Statistics $^{\mathrm{a}}$} \\
\cline { 2 - 5 } & Sample size & $\boldsymbol{\theta}_{\mathrm{s}}$ & $\boldsymbol{\theta}_{\mathrm{n}}$ & Haplotype diversity, $\boldsymbol{h} \pm$ SD \\
\hline Rama $^{\mathrm{b}}$ & 131 & 4.22 & 3.65 & $0.64 \pm 0.04$ \\
Sumu Kat & 15 & 2.46 & 2.74 & $0.34 \pm 0.12$ \\
Punta Águila & 21 & 3.05 & 3.68 & $0.72 \pm 0.06$ \\
Indian River & 10 & 2.82 & 4.13 & $0.60 \pm 0.13$ \\
Greytown & 39 & 2.36 & 3.54 & $0.48 \pm 0.06$ \\
Zompopera & 37 & 2.15 & 4.14 & $0.56 \pm 0.04$ \\
Rama Cay & 80 & 10.9 & 4.05 & $0.65 \pm 0.05$ \\
Mean \pm SD & $33.6 \pm 25.51$ & $3.96 \pm 3.42$ & $3.71 \pm 0.53$ & \\
\hline
\end{tabular}

${ }^{a}$ Two individuals that belong to the haplogroup $\mathrm{H} 2$ and L3 from Greytown were excluded from this analysis.

${ }^{\text {b }}$ Rama includes all six subpopulations.

Guatuso-Maleku, Guaymí, and Matambú-Chorotega; Melton et al. 2013), and it reaches its highest frequency at Rama Cay, Greytown, and Zompopera, is less frequent in Punta Águila and Indian River, and is moderately frequent in Sumu Kat. The starlike shape of this founder haplotype and associated nodes is indicative of population explosion and gain of genetic diversity. Satellite node 16,140-16,168 (identified on Figure 3 as 140 and 168) is present only in Punta Águila and corresponds with haplotype 13 in Table 2. 
Table 4. Time Estimates for Haplogroups A2 and B2 Based in HVS-I Sequences

\begin{tabular}{clc} 
Haplogroup / Haplotype & $\boldsymbol{P} \pm \boldsymbol{\sigma}$ & Years before Present $\pm \mathrm{SD}^{\mathrm{a}}$ \\
\hline $\mathrm{A} 2$ & & \\
\hline 5 & $\begin{array}{l}\text { Ancestral node (16111T, 16223T, 16290T, } \\
16319 \mathrm{~A}, 16362 \mathrm{C})\end{array}$ & $18,000 \pm 15,033$ \\
\hline 1 & $0.957 \pm 0.957$ & $15,957 \pm 15,957$ \\
\hline 2 & $0.881 \pm 0.881$ & $14,845 \pm 14,815$ \\
\hline 3 & $1.80 \pm 0.60$ & $30,000 \pm 10,000$ \\
\hline 6 & $0.66< \pm 0.33$ & $11,111 \pm 5,555$ \\
\hline B2 & & \\
\hline 7 & Ancestral node (16111T, 16217C) & $1,808 \pm 785$ \\
\hline 8 & $0.004 \pm 0.046$ & $683 \pm 683$ \\
\hline 9 & $0.016 \pm 0.016$ & $280 \pm 280$ \\
\hline 10 & $0.016 \pm 0.016$ & $280 \pm 280$ \\
\hline 11 & $0.016 \pm 0.084$ & $282 \pm 141$ \\
\hline 12 & $0.016 \pm 0.016$ & $282 \pm 199$ \\
\hline 13 & $0.025 \pm 0.025$ & $416 \pm 416$ \\
\hline 14 & $0.008 \pm 0.008$ & $141 \pm 141$ \\
\hline 15 & $0.016 \pm 0.016$ & $280 \pm 280$ \\
\hline
\end{tabular}

${ }^{a}$ Time estimates in years from central nodes 5 and 7 were calculated as one mutational event every 16,667 years.

To estimate when lineages emerged from a most recent common ancestor for both haplogroups A2 and B2, the rho statistic ( $\rho$, age in mutations, $\pm \sigma$, standard deviation) was calculated from the constructed networks shown in Figure 3. This statistic indicates the average number of mutations between the root haplotypes 5 and 7 and descendent satellite nodes (Table 4). For haplogroup A2 nodes coalesced at 18,000 $\pm 15,033 \mathrm{YBP}$ (years before present; $\rho \pm \sigma=1.08 \pm 0.90$ ). This time

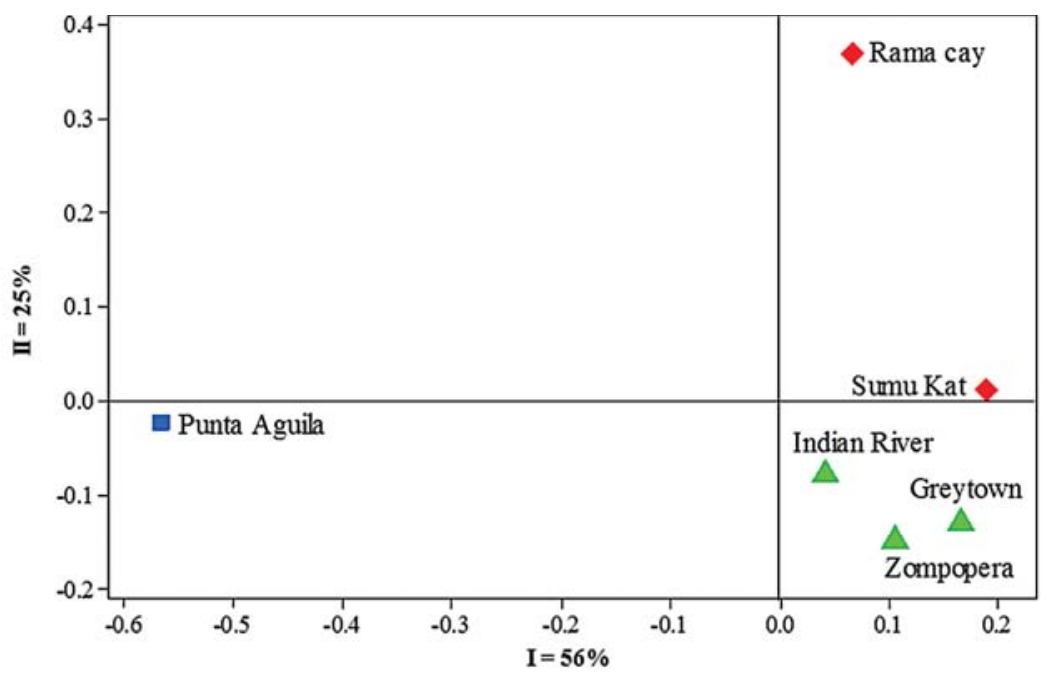

FIGURE 4. Principal component analysis of the $R$-matrix of six Rama subpopulations using mtDNA HVS-I sequences. In this plot the most divergent population is Punta Águila. The two axes (I and II) account for the $81 \%$ of the total variation in the plot. estimate falls within the range of other reported dates for haplogroup A2 (Achilli et al. 2008; Perego et al. 2012; Tamm et al. 2007). Contrary to this scenario, haplotypes that belong to the haplogroup B2 coalesced at $1,808 \pm 785 \mathrm{YBP}(\rho \pm \sigma=0.10 \pm 0.04)$; however, most recent single mutations emerged around 300 YBP and are more frequent in Rama Cay. Only one satellite node of two mutational differences (haplotype 13) away from the basal haplotype (haplotype 7) is present in Punta Águila.

\section{Population Structure}

To ascertain the relationships among the six Rama subpopulations, a PCA plot of the $R$-matrix was constructed using HVS-I sequences (Figure 4). This plot retains $81 \%$ of the total genetic variation within the first and second dimension and separates the geographically peripheral populations of Rama Cay, Sumu Kat, Indian River, Greytown, and Zompopera from a central population, Punta Águila. This isolation is interpreted as a low rate of haplotype sharing between other peripheral Rama subpopulations and Punta Águila. Clusters are caused by differences in haplogroup frequencies. Rama Cay and Sumu Kat have the highest frequency of haplogroup B2 with respect to the lower cluster that includes Indian River and Greytown. Zompopera has equal frequencies of B2 and A2. In Punta Águila, A2 is predominant; for this reason it is an outlier in the diagram.

\section{Genetic Barriers and Phylogeographic Analysis}

Monmonier's algorithm applied to an $F_{S T}$ distance matrix using HVS-I sequences of six Rama communities approximated the location of two genetic barriers, indicating that the first barrier of gene flow isolated Punta Águila from the remaining communities between the Indio Maíz River to the south and the Bay of Bluefields to the north; the second, less robust barrier isolates Zompopera from Sumu Kat and Rama Cay. A possible geographic barrier between these communities is the Kukra River and surrounding forests. The resulting three-dimensional diagram of these barriers depicts the genetic discontinuities among these Rama localities (Figure 5).

Three different hierarchical models were tested using AMOVA to investigate the presence of genetic substructuring within the Rama. Two models were based on geographic separation; the 


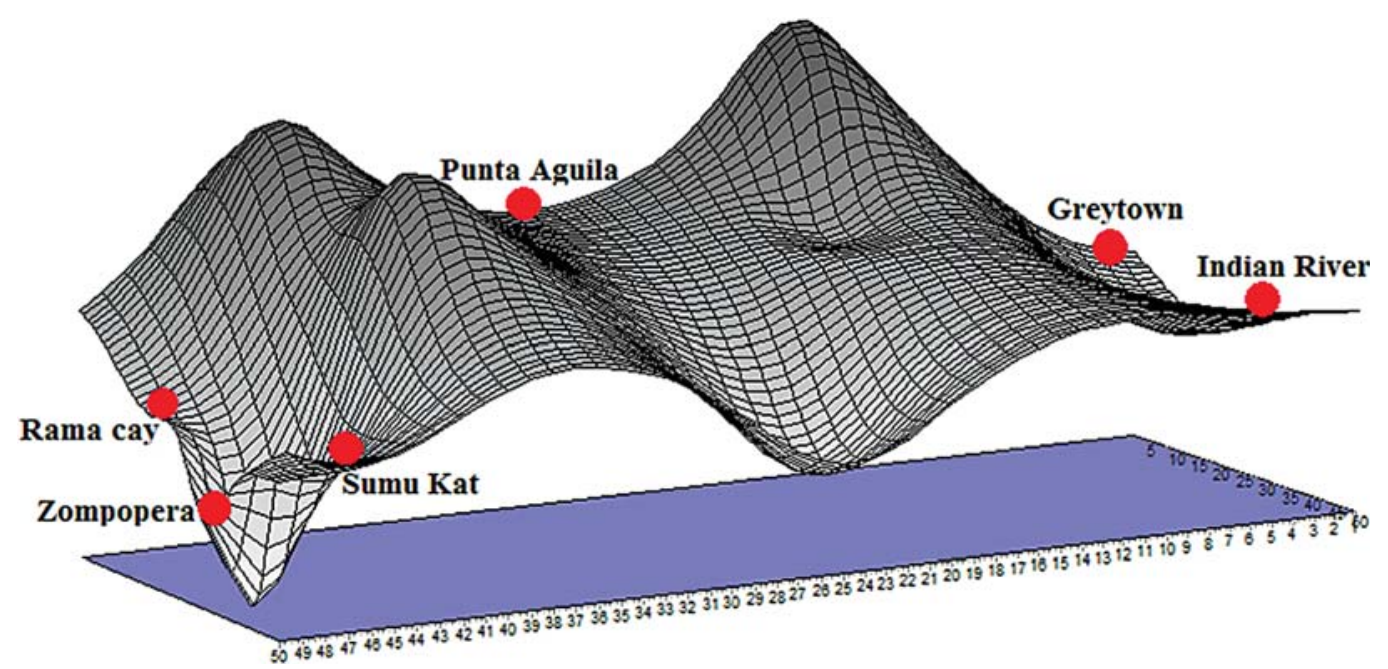

FIGURE 5. Interpolated genetic landscape connecting six Rama localities based on the method of Miller et al. (2006). The surface (z-axis) of this representation is based on genetic distances, and geographical locations of the communities are defined by the $x / y$-axes. In the genetic landscape Punta Águila is the most isolated population, followed by Zompopera. The second, weaker genetic barrier separates Zompopera from Sumu Kat and Rama Cay.

first one separated east-west (Punta Águila and Zompopera) from north-south boundaries and includes Indian River, Greytown, Rama Cay, and Sumu Kat. The second AMOVA divides northern (Sumu Kat, Rama Cay, and Zompopera), central (Punta Águila), and southern Rama localities (Indian River and Greytown). The third AMOVA tested two groups based on kinship relationships previously proposed by Baldi et al. (2014); Punta Águila differentiated from the remaining five localities of the Rama territory.
Table 5 presents the results of the first AMOVA based on the separation of eastern-western and northern-southern localities and shows significant differentiation among these groupings $\left(F_{C T}=\right.$ $0.10183, p<0.001)$. Nonetheless the correlation among subpopulations within the Rama population as a whole was not significant $\left(F_{S C}\right)$, although this component shows low values in the geography II and kinship groupings. The second AMOVA shows that $93.6 \%$ of the HVS-I variation is shared within northern, central, and southern localities,

Table 5. Analysis of Molecular Variance of Five Rama Subpopulations

\begin{tabular}{|c|c|c|c|c|c|}
\hline Subdivision / Group & Subpopulations & Source of variation & $\begin{array}{l}\text { Percentage } \\
\text { of variation }\end{array}$ & F-statistic & $P$-Value \\
\hline \multicolumn{6}{|l|}{ Geography I } \\
\hline East-West & Punta Águila, Zompopera & Among groups & 10.18 & $F_{C T}=0.10183$ & $<0.001$ \\
\hline \multirow[t]{2}{*}{ North-South } & $\begin{array}{l}\text { Indian River, Greytown, } \\
\text { Rama Cay }\end{array}$ & Among subpop. between groups & 0.42 & $F_{S C}=0.00465$ & n.s. \\
\hline & & Within subpop. & 89.4 & $F_{S T}=0.10600$ & $<0.05$ \\
\hline \multicolumn{6}{|l|}{ Geography II } \\
\hline North & $\begin{array}{l}\text { Sumo Kat, Rama Cay, } \\
\text { Zompopera }\end{array}$ & Among groups & 0.54 & $F_{C T}=0.00540$ & n.s. \\
\hline Central & Punta Águila & Among subpop. between groups & 5.87 & $F_{S C}=0.05900$ & $<0.05$ \\
\hline South & Indian River, Greytown & Within subpop. & 93.59 & $F_{S T}=0.06408$ & $<0.05$ \\
\hline \multicolumn{6}{|l|}{ Kinship } \\
\hline Central & Punta Águila & Among groups & 10.12 & $F_{C T}=0.10123$ & $<0.001$ \\
\hline \multirow{2}{*}{ Peripheral } & \multirow{2}{*}{$\begin{array}{l}\text { Sumo Kat, Rama Cay, } \\
\text { Zompopera, Indian River, } \\
\text { Greytown }\end{array}$} & Among subpop. between groups & 3.26 & $F_{S C}=0.03629$ & $<0.05$ \\
\hline & & Within subpop. & 86.62 & $F_{S T}=0.13385$ & $<0.05$ \\
\hline
\end{tabular}


whereas $6 \%$ was attributed among communities and between groups, and the remaining $0.5 \%$ of the variation is not significant when northern, central, and southern groups of communities are compared $\left(F_{C T}=0.0054\right)$. Zompopera is included in the northern group.

The AMOVA based on close kin affiliation between Punta Águila (central population) and the peripheral populations reveals that the highest ( $87 \%$ of the variation) is present within individual subpopulations, and 10\% is among groups (Table $5)$. The fixation index $F_{C T}=0.10123(p<0.001)$ accounts for the variation among central and peripheral groups.

\section{Discussion}

\section{Mitochondrial Diversity}

Mitochondrial DNA haplogroups within the Rama belong to two (A2, B2) of the four major founding macro haplogroups (A, B, C, and D) in the Americas (Torroni et al. 1993; Wallace and Torroni 1992), as well as the African haplogroup L3 and the European haplogroup H2. These results differ somewhat from previously published results (Melton et al. 2013) due to the presence of two new haplogroups (H2 and L3). The percentages also changed due to the augmentation of the sample size (B2, 71\%; A2, $28 \%$; H2, 0.5\%; and L3, 0.5\%). Despite the new identification of two nonindigenous haplogroups in the Rama's gene pool, haplogroup B2 is still the most frequent.

Haplotype 7 of haplogroup B2 (16189C, 16217C) is the most common among the Rama and is shared with other SCA Kuna, Emberá, Zapatón-Huetar, Guatuso-Maleku, Guaymí, and Chorotega populations (Melton et al. 2013). The remaining B2 Rama haplotypes (3, 4, 8-15 in Table 2) have not been detected among other SCA Chibchan populations. The time estimates of all variants in the B2 lineage were dated to historical times, around $1700 \mathrm{CE}$, a date congruent with the relocation in the 18th century of a group of Voto-Rama Amerindians from the San Juan River refuge to Punta Gorda, including Punta Águila, lands historically occupied by the Rama in Nicaragua (Incer and Pérez-Valle 1999; Kemble 1884; Schnaider 1989). The recent population expansion shown in the network analysis of haplogroup B2 (Figure 3, right) suggests that gene flow between neighboring Voto-Rama demes around 300 years ago might explain the high frequency of private haplotypes in today's Rama gene pool (see Ray et al. 2003); thus, the same variants should be expected in genetically related extant and extinct populations in northern Costa Rica.

The second most common variant (haplotype 1) of haplogroup A2 (16111T, 16187T, 16223T, 16290T, $16319 \mathrm{~A}, 16362 \mathrm{C}$ ) is shared with a number of Central American Chibchans (Maleku, Guaymí, and Ngöbé), Mesoamericans populations, and nonChibchan speakers from South America (Baldi 2013). According to the mtDNA molecular clock, haplogroup A2 most likely coalesced around 18,000 YBP. This estimation falls within the most accepted time of colonization of Central America between 15,000 and 19,000 YBP based on mtDNA (Perego et al. 2012).

Haplogroup L3 is indicative of African admixture with the Rama, and one individual in Greytown, belonging to the haplogroup $\mathrm{H} 2$, also indicates recent European admixture. The gene flow between individuals of African and European ancestry was probably recent (Battistuzzi et al. 1986), and it is more frequent at Rama Cay, Punta Águila, and Greytown than in any other Rama community according to admixture estimations obtained from previous surname analysis and a recent demographic survey (Baldi et al. 2014; Gobierno Territorial Rama y Kriol 2007).

According to the genetic diversity estimators $h$ and $\Theta_{s}$ applied only to native American haplogroup variation among the Rama, Rama Cay and Punta Águila are more genetically diverse populations than the other communities, whereas values of nucleotide diversity are similar (average $=4.05$ ) among localities. The relative values derived from the diversity index $\Theta_{s}$ and $h$ are consistent with the unbiased isonymy values $\left(I_{i i}\right)$ calculated by Baldi et al. (2014), which indicated that Rama Cay and Punta Águila are the more diverse subpopulations, Greytown and Zompopera are intermediate, and Indian River and Sumu Kat are the less diverse and more isolated subpopulations.

\section{Genetic Substructure and History of the Rama}

The network analysis for haplogroup A2 reveals a past population reduction (i.e., genetic bottleneck) in which the most ancestral node (II) is shared by only two communities, Punta Águila and Rama 
Cay, and is linked to other haplotypes of major frequency. Contrary to this, the starlike phylogeny of haplogroup B2 is characterized by a number of singletons that radiate from a large central node, indicating recent population expansion (Figure 3 , right). Overall, haplogroup A2 is more frequent in Punta Águila than is haplogroup B2, which is more common among the other five Rama subpopulations: Greytown, Zompopera, Rama Cay, Sumu Kat, and Indian River. The relationships of the haplotypes 2 and 3 of haplogroup A2 is depicted in the phylogenetic network (Figure 3, left), where haplotype 2 (node III) is highly frequent in Punta Águila but is shared in low frequencies among Rama Cay, Indian River, and Zompopera; and haplotype 3 (node V) is shared in low frequencies between Punta Águila, Zompopera, and Greytown. Haplogroup B2 shows a contrasting scenario of only one maternal relationship through haplotype 7 between Punta Águila and other Rama communities.

The genetic differentiation of central and peripheral populations was tested using AMOVA on mtDNA sequences. This analysis reveals that $10 \%$ of the genetic variation among central and peripheral groups resulted from kin affiliation $\left(F_{C T}=0.10\right.$, $p<0.001)$; nevertheless, the correlation of Punta Águila and Zompopera and a group that includes the remaining northern and southern communities shows a similar $F_{C T}$ value. This relationship is not surprising since Punta Águila and Zompopera share A2 haplotypes, indicating kin relationships, a finding supported by analyses of surname isonymy showing affinities between the two communities (Baldi et al. 2014).

Congruent with AMOVA analyses, Monmonier's algorithm found a strong genetic barrier of gene flow that separates Punta Águila (central population) from the peripheral communities, and a less robust barrier of gene flow isolates Zompopera (Figure 5). Geographically, the strongest barrier is likely to be situated between the Bay of Bluefields and the Punta Gorda River.

Additional support of maternal genetic difference between Punta Águila and the peripheral Rama communities comes from the median networks and the PCA of the R-matrix (Figure 4). These analyses show that in Punta Águila A2 haplotypes are more frequent compared with peripheral communities, where B2 is higher. Based on these analyses, affinal relationships based on kin might have deep historical roots that have persisted until the present. According to Baldi et al. (2014), marital practices, probably based on assortative mating, created consanguineal relationships and alliances that underlie the maternal genetic structure of the Rama and endured for generations, explaining the observed subdivision between central or peripheral communities. Affinal aggregation and vicinage are not random because it is based on generations of arranged marriages (explicit or not) with other known family groups (Loveland 1975).

The genetic structure of these central and peripheral groups suggests two evolutionary stories in concordance with their relative geographic isolation, migration, and kin structure. From the mitochondrial perspective, haplogroups A2 (haplotype 2) and B2 (haplotype 13) appear to be more related with the central population, Punta Águila, and are less diffused among peripheral Rama communities such as Zompopera. This situation leads to the proposal that these haplotypes were restricted to maternal lineages in the Punta Gorda region due to reduced genetic flow with other peripheral groups.

In conclusion, the peripheral group could represent a remnant population of the colonial Voto (Voto-Rama), whose descendants migrated first to Punta Gorda and then split at the end of the 18th century to the Bay of Bluefields, while a central group (including Punta Águila and surrounding communities) may have remained in the region of Punta Gorda for many generations.

\section{ACKNOWLEDGMENTS}

We thank the Rama participants in this study, especially Cleveland Macrea and Jerry Macrea, as well as Lorenzo Martinez and Nazario Martinez, for their kind assistance and support during fieldwork. We hope that this investigation will help the Rama in their struggle to reclaim their ancestral lands. Funding for this research was provided by a Carroll D. Clark Award and by a Summer Research Fellowship from the University of Kansas.

Received 11 January 2016; revision uploaded 10 April 2016. 


\section{LITERATURE CITED}

Achilli, A., U. A. Perego, C. M. Bravi et al. 2008. The phylogeny of the four pan-American mtDNA haplogroups: Implications for evolutionary and disease studies. PLoS One 3:el764.

Andrews, R., I. Kubacka, P. Chinnery et al. 1999. Reanalysis and revision of the Cambridge Reference Sequence for human mitochondrial DNA. Nat. Genet. 23:147.

Assandi, B. 1983. Rama Cay Creole. In Varieties of English around the World, Vol. T2, Central American English, J A. Holm, ed. Heidelberg: Groos, 115-122.

Baldi, N. 2013. Genetic structure and biodemography of the Rama Amerindians from the southern Caribbean coast of Nicaragua. Ph.D. diss., University of Kansas.

Baldi, N., P. Melton, and M. H. Crawford. 2014. Effect of recent historical events on migration and isonymic stratification among the Rama Amerindians from Nicaragua. Hum. Biol. 86:37-50.

Bandelt, H. J., P. Forster, and A. Röhl. 1999. Median-joining networks for inferring intraspecific phylogenies. $\mathrm{Mol}$. Biol. Evol. 16:37-48.

Barrantes, R. 1993. Evolución en el Trópico: Los Amerindios de Costa Rica y Panamá. San José: Editorial de la Universidad de Costa Rica.

Battistuzzi, G., G. Biondi, O. Rickards, et al. 1986. Historical and demographic factors and the genetic structure of an Afroamerican community of Nicaragua. In Genetic Variation and Its Maintenance, D. F. Roberts and G. F De Stefano, eds. Cambridge: Cambridge University Press, $180-189$

Clark, C., F. G. Dawson, and J. C. Drake. 1984. Archaeology on the Mosquito Coast: A Reconnaissance of the PreColumbian and Historic Settlement along the Rio Tinto. Cambridge: Centre for Latin American Studies.

Constenla, A. 2008. Estado actual de la subclasificación de las lenguas chibchenses y de la reconstrucción fonológica y gramatical del protochibchense. Lingüística Chibcha 27:117-135.

Conzemius, E. 1927. Die Rama Indianer von Nicaragua. $Z$. Etnol. 59: 261-362.

Conzemius, E. 1930. Una tribu incomme du Costa Rica: Les Indiens Rama du Rio Zapote. L'Anthropologie 40:93-108.

Conzemius, E. 1938. Les tribus Indiennes de la Cote de Mosquitos. Anthropos 33:910-943.

Craig, C. 1990. Review of the Dictionary of the Rama Language. Int. J. Am. Linguist. 56:293-304.

D’Aloja, A. 1939. Informe sobre la Investigación AntropológicaDemográfica Realizada en Centroamérica. México, DF Instituto Panamericano de Geografía e Historia.
De Stefano, G. F. 1973. A study of morphological and genetic distance among four Indian villages of Nicaragua. $J$. Hum. Evol. 2:231-240.

Dupanloup, I., S. Schneider, and L. Excoffier. 2002. A simulated annealing approach to define the genetic structure of populations. Mol. Ecol. 11:2,571-2,581.

Excoffier, L., P. E. Smouse, and J. M. Quattro. 1992. Analysis of molecular variance inferred from metric distances among DNA haplotypes: Application to human mitochondrial DNA restriction data. Genetics 131:479-491.

Gobierno Territorial Rama y Kriol. 2007. Diagnóstico del Territorio Rama y Kriol. Bluefields, Nicaragua: Gobierno Territorial Rama y Kriol. http://enlaceacademico.ucr. ac.cr/node/383.

Hall, T. A. 1999. BioEdit: A user friendly biological sequence alignment editor and analysis program for Windows 95/98/NT. Nucl. Acids Symp. 41:95-98.

Harpending, H., and T. Jenkins. 1973. Genetic distance among southern African populations. In Methods and Theories of Anthropological Genetic, M. H. Crawford and P. Workman, eds. University of New Mexico Press, 177-199.

Harpending, H., and A. Rogers. 1984. ANTANA: Package for Multivariate Data Analysis. V.1.1. Distributed by the authors.

Ibarra, E. 2011. Los Nicaraos, los Indios Votos y los Huetares en escenarios conflictivos en el siglo XVI. Cuad. Antropol. 21:1-24.

Incer, J. 1975. Geografía Ilustrada de Nicaragua. Bogotá: Editora y Distribuidora Nicaragüense.

Incer, J., and E. Pérez-Valle. 1999. Descubrimiento y Explotación del Río San Juan. Managua: HIPAMER.

Kemble, S. 1884. Journals of Brigadier-General Kemble. In The Kemble Papers: Brigadier-General in Command of the Expedition to Nicaragua, 1780-1781, E. De Lancey, G. Moore, and W. Libbey, eds. New York: New York Historical Society Publication Fund, 31-101.

Loveland, F. 1975. Dialectal aspects of natural symbols: Order and disorder in Rama Indian cosmology. Ph.D. diss. University of Michigan, Ann Arbor.

Magnus, R. M. 1974. The prehistory of Miskito Coast of Nicaragua: A study in cultural relationships. Ph.D. diss., Yale University.

Manni, F., and E. Guerard. 2004. Barrier vs 2.2. Manual of the User. Paris: Musee de l'Homme.

Manni, F., E. Guerard, and E. Heyer. 2004. Geographic patterns of (genetic, morphologic, linguistic) variation: How barriers can be detected by Monmonier's algorithm. Hum. Biol. 76:173-190.

Melton, P., N. Baldi, R. Barrantes et al. 2013. Microevolution, 
migration, and the population structure of five Amerindian populations from Nicaragua and Costa Rica. Am. J. Hum. Biol. 25:480-490.

Meyer, S., G. Weiss, and A. von Haeseler. 1999. Pattern of nucleotide substitution and rate heterogeneity in the hypervariable regions I and II of human mtDNA. Genetics 152:1,103-1,110.

Miller, M. K., M. R. Bellinger, E. D. Forsman et al. 2006. Effects of historical climate change, habitat connectivity, and vicariance on genetic structure and diversity across the range of the red tree vole (Phenacomys longicaudus) in the Pacific northwestern United States. Mol. Ecol. 15:145-159.

Miller, M. P. 2005. Alleles in space (AIS): Computer software for the joint analysis of interindividual spatial and genetic information. J. Hered. 96:722-724.

Monmonier, M. S. 1973. Maximum-difference barriers: An alternative numerical regionalization method. Geogr. Anal. 5:245-261.

Perego, U. A., H. Lancioni, M. Tribaldos et al. 2012. Decrypting the mitochondrial gene pool of modern Panamanians. PLoS One 7:e38337.

Ray, N., M. Currat, and L. Excoffier. 2003. Intra-deme molecular diversity in spatially expanding populations. Mol. Biol. Evol. 20:76-86.

Reich, D., N. Patterson, D. Campbell et al. 2012. Reconstructing Native American population history. Nature 488:370-374.

Riverstone, G. 2004. Living in the Land of Our Ancestors. Managua: Imprimatur.

Romero, G. 1995. Las Sociedades del Atlántico de Nicaragua en los Siglos XVII y XVIII. Managua: Colección Cultural Banco Nicaragüense.

Schnaider, R. 1989. Rama and the Sandinist Revolution. Berlin: Reimer.

Schultz, A. H. 1926. Anthropological studies of the Nicaraguan Indians. Am. J. Phys. Anthropol. 9:65-79.

Schurr, G., S. W. Ballinger, Y. Y. Gan et al. 1990. Amerindian mitochondrial DNAs have rare Asian mutations at high frequencies, suggesting they derived from four primary maternal lineages. Am. J. Hum. Genet. 46:613-623.

Smutko, G. 1988. La Mosquitia: Historia y Cultura de la Costa
Atlántica. Managua, Nicaragua: Editorial La Ocarina.

Soares, P., L. Ermini, N. Thomson et al. 2009. Correcting for purifying selection: An improved human mitochondrial molecular clock. Am. J. Hum. Genet. 84:740-759.

Solórzano, J. C. 2000. Los Indígenas en las áreas fronterizas de Costa Rica durante el siglo XIX. Avances de Investigación, Centro de Investigaciones Históricas 78:1-39.

Stone, D. 1972. Pre-Columbian Man Finds Central America: The Archeological Bridge. Cambridge, MA: Peabody Museum Press.

Tamm, E., T. Kivisild, M. Reidla et al. 2007. Beringian standstill and spread of Native American founders. PLoS One 2:e829.

Tamura, K., and M. Nei. 1993. Estimation of the number of nucleotide substitutions in the control region of mitochondrial DNA in humans and chimpanzees. Mol. Biol. Evol. 10:512-526.

Thompson, E. A., J. V. Neel, P. E. Smouse et al. 1992. Microevolution of the Chibcha-speaking of Lower Central America: Rare genes in an Amerindian complex. Am. J. Hum. Genet. 51:609-626.

Torroni, A., T. G. Schurr, M. F. Cabell et al. 1993. Asian affinities and continental radiation of the four founding Native American mtDNAs. Am. J. Hum. Genet. 53:563-590.

van Oven, M. 2010. Revision of the mtDNA tree and corresponding haplogroup nomenclature. Proc. Natl. Acad. Sci. USA 107:E38-E39.

van Oven, M., and M. Kayser. 2009. Updated comprehensive phylogenetic tree of global human mitochondrial DNA variation. Hum. Mutat. 30:E386-E394.

Wallace, D. C., and A. Torroni. 1992. American Indian prehistory as written in mitochondrial DNA: A review. Hum. Biol. 63:403-416.

Walsh, P. S., D. A. Metzger, and R. Higuchi. 1991. Chelex 100 as a medium for simple extraction of DNA for PCR-based typing from forensic material. Biotechniques 10:506-513.

Wang, S., C. M. Lewis, M. Jakobsson et al. 2007. Genetic variation and population structure in Native Americans. PLoS Genet. 3:e185. 
Copyright of Human Biology is the property of Wayne State University Press and its content may not be copied or emailed to multiple sites or posted to a listserv without the copyright

holder's express written permission. However, users may print, download, or email articles for individual use. 